WHOI-89-43

\title{
Bibliography of Technical Reports 1988
}

Compiled by

\author{
Susan S. Putnam
}

Woods Hole Oceanographic Institution

Woods Hole, Massachusetts 02543

October 1989

Reproduction in whole or in part is permitted for any purpose of the United States Government. This report should be cited as: Woods Hole Oceanog. Institution Technical Report WHOI-89-43.

Approved for publication; distribution unlimited.

Approved for Distribution:

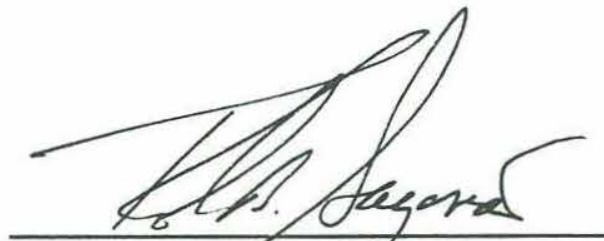

Dr. Robert B. Gagosian

Associate Director for Research 
The technical reports prepared by the Woods Hole Oceanographic Institution in 1988 are 1 isted in this bibliography. Inquiries about availability of extra copies will be handed on an individual basis. Initial distribution of the reports is controlled by the funding agencies. Reports are available through the:

\author{
National Technical Information Service \\ NTIS Order Desk \\ 5285 Port Roya 1 Road \\ Springfie1d, VA 22161
}

NTIS order numbers are included with each report 1 isted or can be obtained through the Document Library.

The Document Library provides Interlibrary Loan service for al1 Institution reports and will assist with problens of identification.

When citing a report, it should be referenced as: Woods Hole Oceanographic Institution Technical Report WHOI-88-No.

A11 reports 1 isted are UNCLASSIFIED and approved for pub1ic release unless otherwise noted.

Document Library - C1ark 141

Woods Hole Oceanographic Institution

Hoods Hole, MA 02543 


\section{Technica1 Reports - 1988}

WHOI

88- 1 Putna: Susan S.

Bibliography of technical reports 1987. Apr 1988. 14p. NTJS NO. PB88-201 942/AS.

WHOI

88- 2 Watkins, Willian A., James E. Bird, Karen E. Moore and Peter Tyack.

Reference database marine mammal 1iterature. Jan $1988.82 \mathrm{p}$. NTIS NO. PB89-204 549/AS.

WHOI

88- 3 Kaninski, Hichae1 $\mathbf{A}$.

Cenozoic deep-water agglutinated foraminifera in the North Atlantic. Ph.D. Thesis. MIT/WHOI Joint Program in

Oceanography and Oceanographic Engineering. Dec 1987. 262p. NTIS NO. PB89-198 121/AS.

WHOI

88- 4 Goud, Margaret Redding.

Prediction of continental she1f sediment transport using a theoretical model of the wave-current boundary 1ayer. Ph.D. Thesis. MIT/WHOI Joint Program in Oceanography and Oceanographic Engineering. Ang 1987. 211p. NTIS NO. AD-A192 272 .

WHOI

88- 5 Brighan, Lawson . and E11en M. Gately.

The Soviet Maritime Arctic. Proceedings of a workshop held May 10-13, 1987 by the Marine Policy Center of the Woods Hole Oceanographic Institution, Woods Hole, Massachusetts 02543 USA. Jan 1988. 67p. NTIS NO. PB89-200 877/AS.

WHOI

88- 6 Kite-Powe11, Hauke.

A broad-scale profile of the marine advanced technology industry. Mar 1988. 80p. NTIS NO. PB88-210588.

WHOI

88- 7 Sta1cup, M. C., T. M. Joyce, J. L. Bu11ister, R. L. Barbour and J.A. Dunworth.

Hydrographic data from R/V ENDEAVOR Cruise \#143. Mar 1988. $118 \mathrm{p}$. NTIS NO. PB89-204 382/AS.

WHOI

88- 8 Casso, Susan A., Milliam R. Clarke, Hugh D. Livingston, Julianne M. Palmieri and Lolita D. Suprenant. Cesium and strontiun isotopes in the northwestern north Atlantic and Arctic Ocean, 1981 - 1985. Apr 1988. 47p. NTIS NO. PB89-203 913/AS. 
WHOI

88- 9 Ponte, Rui Vasques de He10.

Observations and mode11ing of deep equatorial currents in the Centra1 Pacific. Ph.D. Thesis. MIT/WHOI Joint Program in Oceanography and Oceanographic Engineering. Jan 1988. 184p. NTIS NO. PB89-198 139/AS.

WHOI

88-10 Vacongne, Sophie.

Dynamics of the equatorial undercurrent and its termination. Ph.D. Thesis. MIT/WHOI Joint Program in Oceanography and Oceanographic Engineering. Jan 1988. 365p. NTIS NO. PB89-198 147/AS.

WHOI

88-11 Wengrovitz, Michae1 S.

The Hilbert-Hanke1 transform and its application to sha11ow water ocean acoustics. Sc.D. Thesis. MIT/WHOI Joint Program in Oceanography and Oceanographic Engineering. Jan 1986. $483 \mathrm{p}$.

WHOI

88-12 Kerab, Andre A.

Exact reconstruction of ocean bottom velocity profiles from monochromatic scattering data. Sc.D. Thesis. MIT/WHOI Joint Prograni in Oceanography and Oceanographic Engineering. Jan 1987. 204p.

WHOI

88-13 Tziperman, E1i.

Mixing and general circulation dynamics: Theory and observations. Ph.D. Thesis. MIT/WHOI Joint Program in Oceanography and Oceanographic Engineering. Feb 1987. 165 p. NTIS NO. PB89-198 063/AS.

WHOI

88-14 Tricca, A1ice $I$. Abstracts of papers submitted in 1987 for publication. Apr 1988. 92p. NTIS NO. PB88-246 913/AS.

WHOI

88-15 Briscoe, $M_{\text {, }}$ E. Denton, D. Frye, M. Hunt, E. Montgomery and $R$. Payne.

Surface-wave data acquisition and dissemination by VHF packet radio and computer networking. Apr 1988. 113p. NTIS NO. $\mathrm{AD}-\mathrm{A} 197547$.

WHOI

88-16 Ma1kus, Vil1iam V. R. and Mary Evans Berry. Summer Study Program in Geophysical Fluid Dynamics. Order and disorder in planetary dynamos. May 1988. 164p. NTIS NO. $\mathrm{AD}-\mathrm{A} 196554$. 
WHOI

88-17 Catipovic, Josko A.

Design and performance analysis of a digital acoustic

telemetry system. Sc.D. Thesis. MIT/WHOI Joint Program in

Oceanography and Oceanographic Engineering. May 1988. 268p.

WHOI

88-18 Villey, Joanne $\mathrm{H}$.

Characterization of swimming motility in a marine unicel1ular cyanobacterium. Ph.D. Thesis. MIT/WHOI Joint Progran in Oceanography and Oceanographic Engineering. Apr 1988. 162p. NTIS NO. PB89-198 071/AS.

WHOI

88-19 Casey, Kevin D.

A moda1/WKB inversion method for determining sound speed profiles in the ocean and ocean botton. 0.E. Thesis. MIT/WHOI Joint Program in Oceanography and Oceanographic Engineering. Jun 1988, 103p.

WHOI

88-20 Dean, Jerome P. and Robert C. Beards1ey. A Vector - Averaging Wind Recorder (VAWR) system for surface meteorological measurements in CODE (Coasta1 Ocean Dynamics Experiment). May 1988. 74p. NTIS NO. PB89-203 921/AS.

WHOI

88-21 Little, Sarah A.

F1uid flow and sound generation at hydrothermal vent fields. $\mathrm{Ph} . D$. Thesis. MIT/WHOI Joint Program in Oceanography and Oceanographic Engineering. Apr 1988. 152p.

WHOI

88-22 Hering, Janet $G$.

The kinetics and the rmodynamics of copper complexation in aquatic systems. Ph.D. Thesis. MIT/WHOI Joint Program in Oceanography and Oceanographic Engineering. Jun 1988. 308p.

WHOI

88-23 Speer, Kevin G.

The influence of geothermal sources on deep ocean temperature, salinity, and flow fields. Ph.D. Thesis. MIT/WHOI Joint Program in Oceanography and Oceanographic Engineering. Jun 1988. 146p. NTIS NO. PB89-198 089/AS.

WHOI

88-24 Diebe1, Caro1 E.

The sensory mediation of symbiosis between hyperiid amphipods and salps. Ph.D. Thesis. MTT/WHOI Joint Program in Oceanography and Oceanographic Engineering. Jun 1988. 192p. NTIS NO. PB89-198 725/AS. 
WHOI

88-25 Jemsek, John P.

Heat flow and tectonics of the Ligurian Sea Basin and

margins. Ph. Thesis. MIT/WHOI Joint Program in Oceanography and Oceanographic Engineering. Jun 1988. 488p. NTIS NO.

PB89-198 154/AS.

WHOI

88-26 Benoit, Gaboury.

The biogeochemistry of $210 \mathrm{~Pb}$ and $210 \mathrm{Po}$ in fresh waters

and sediments. Ph.D. Thesis. MIT/WHOI Joint Program in

Oceanography and Oceanographic Engineering. Jun 1988. 304p.

NTIS NO. PB89-198 097/AS.

WHOI

88-27 Bbinger, Cynthia $J$.

Therma1 and mechanical development of the East African Rift

system. Ph.D. Thesis. MIT/WHOI Joint Program in

Oceanography and Oceanographic Engineering. Ju1 1988. 180p.

NTIS NO. PB89-203 632/AS.

WHOI

88-28 Jasper, John $P$.

An organic geochemical approach to problems of

g1acia1-interg1acia1 c1imatic variabi1ity. Ph.D. Thesis.

MIT/WHOI Joint Program in Oceanography and Oceanographic

Engineering. Ju1 1988. 312p. NTIS N0. PB89-198 162/AS.

WHOI

88-29 Segal, Mordechai and Ehud Weinstein.

Time delay estimation in stationary and non-stationary

environments. Ju1 1988. 75p.

WHOI

88-30 Kinder, Thomas H. and Harry L. Bryden.

Gibra1ter Experiment: Summary of the field program and initial results of the Gibralter Experiment. Aug 1988. 121F. NTIS NO. AD-A199 445/8/WOT.

WHOI

88-31 Ba11, L. A. and F. L. Sayles.

The release and migration of activation products of

corrosion-resistant metal specimens in marine sediments. Aug 1988. 37p. NTIS NO. PB88-251 186.

WHOI

88-32 Berteaux, H., A. Bocconce11i, M. Gou1d and S. Kery.

Testing and evaluation of SURLYN foan and SPECTRA $f$ iber ropes for buoy systems applications. Aug 1988. 31p. NTIS NO.

AD-A199 882/XAB.

WHOI

88-33 Jaffe, Jules S.

Underwater imaging system performance characterization. Aug 1988. 52p. NTIS NO. AD-A199 529/9/WOT. 
WHOI

88-34 Gray, E1isabeth S.

Sexual patterns of monooxygenase function in the 1 ive $x$ of

marine teleosts and the regulation of activity by estradiol.

Ph.D. Thesis. MIT/WHOI Joint Program in Oceanography and

Oceanographic Engineering. Aug 1988. 154p. NTIS NO.

PB89-198 170/AS.

WHOI

88-35 Honjo, S., B. J. Hay, Oya Algan, Vernon Asper, Huseyin Ben1i,

Tayfun Bilgic, James Broda, Walter Dean, Egon T. Degans, Alan Gagnon, Bonnie L. Woodward and A. Sami Derman.

Temporal and spatial variability in sedimentation in the

Black Sea: Cruise Report R/V KNORR 134-8, B1ack Sea Leg 1, Apri1 16-May 7, 1988. Oct 1988. 167p. NTIS NO. PB89-204

$366 /$ AS .

WHOI

88-36 Lawrence, Fendy $B$.

Measurements of a barotropic planetary vorticity mode in an eddy-resolving quasi-geostrophic model using acoustic tomography. S.M. Thesis. MIT/WHOI Joint Program in Oceanography and Oceanographic Engineering. Aug 1988. 30p. NTIS NO. AD-A205 409.

WHOI

88-37 Rowe, B1izabeth Anne.

Improvement of three dimensional acoustic field estimation using tomographic reconstructions of the ocean. S.M. Thesis. MIT/WHOI Joint Program in Oceanography and Oceanographic Engineering. Aug 1988. 55p. NTIS NO. AD-A207 664.

WHOI

88-38 Nicholson, John W.

Registration and variability of side scan sonar imagery. 0.E. Thesis. MIT/WHOI Joint Program in Oceanography and Oceanographic Engineering. Aug 1988. 102p. NTIS NO. AD-A201 895.

WHOI

88-39 Vaughn, Gregory .

Hybrid state estimators for the control of remotely operated underwater vehicles. O.E. Thes is and S. M. Thesis. MIT/WHOI Joint Program in Oceanography and Oceanographic Engineering. Sep 1988. 118p.

WHOI

88-40 Campbe11, Jeffrey

Evaluation of GEOSAT data and application to variability of the northeast Pacific Ocean. S.M. Thesis. MIT/WHOI Joint Program in Oceanography and Oceanographic Engineering. Oct 1988. $167 p$. 
WHOI

88-41 Knapp, George P.

Hydrographic data from RV ENDEAVOR Cruise 129. Sep 1988. 111p. NTIS NO. PB89-204 556/AS.

WHOI

88-42 Joyce, T. M., J. A. Dunworth, D. M. Schubert, M. C. Stalcup and $R$. L. Barbour.

Application of acoustic-doppler current profiler and expanable bathythermograph measurements to the study of the velocity structure and transport of the Gulf Stream. Sep 1988. 27p. NTIS NO. N88-28605/9/XAB.

WHOI

88-43 Zemanovic, M., P. Richardson, J. Valdes, J. Price and L. Arai.

SOFAR float Mediterranean Outflow Experiment data from the second year, 1985 - 1986. Sep 1988. 238p. NTIS NO. PB89-204 $606 / \mathrm{AS}$.

WHOI

88-44 Holderied, Kristine.

Comparison study of SEASAT scatterometer and convential wind fie1ds. S.M. Thesis. MIT/WHOI Joint Program in Oceanography and Oceanographic Engineering. Oct 1988. 221p.

WHOI

88-45 Freise, C1arke B.

A comparison of cross-stream velocities and Gulf Stream translations utilizing in-situ and remotely-sensed data. S.M. Thesis. MIT/WHOI Joint Program in Oceanography and Oceanographic Engineering. Oct 1988. 48p.

WHOI

88-46 Venne11, M. Ross.

The influence of a steady baroclinic deep ocean on the shelf. Ph.D. Thesis. MIT/WHOI Joint Program in Oceanography and Oceanographic Engineering. Oct 1986. 202p. NTIS NO. PB89-198 188/AS.

WHOI

88-47 Wilkin, John L.

Scattering of coasta1-trapped waves by irregularities in coastline and topography. Ph.D. Thesis. MIT/WHOI Joint Program in Oceanography and Oceanographic Engineering. Oct 1988. 124p. NTIS NO. PB89-198 105/AS.

WHOI

88-48 Polvani, Lorenzo M.

Geostrophic vortex dynamics. Ph.D. Thesis. MIT/WHOI Joint Progran in Oceanography and Oceanographic Engineering. Oct 1988. 225p. 
WHOI

88-49 Vengayil, Padmaraj.

Similarity relations of wind waves in finite depth. S.M. Thesis. MIT/WHOI Joint Program in Oceanography and Oceanographic Engineering. Nov 1988. 95p. NTIS NO. PB89-198 $113 /$ AS.

WHOI

88-50 Choi, Joon Von.

The effects of algal density on growth of heterotrophic microflage11ates. S.M. Thesis. MIT/WHOI Joint Program in Oceanography and Oceanographic Engineering. Nov 1988. 79p. NTIS NO. PB89-198 196/AS.

WHOI

88-51 Bennett, Sara L.

Where three oceans meet: The Agulhas Retroflection region. Ph.D. Thesis. MIT/WHOI Joint Program in Oceanography and Oceanographic Engineering. Oct 1988. 371p. NTIS NO. AD-A204 684.

WHOI

88-52 Montgomery, E11yn T.

Richardson Number (RiNo) float operations during the Patch Experiment (PATCHEX), and data summary. Nov 1988. 28p. NTIS NO. AD-A205 343.

WHOI

88-53 Hennet, Reay J-C. and Jean $K$. Whelan.

In-situ chemical sensors for detecting and exploring ocean floor hydrothermal vents. Report of a workshop. Nov 1988. 75p. NTIS NO. PB89-156 624.

WHOI

88-54 Hammer,. T. R., P. L. Sachs and M. P. Bacon.

A modified wire clamp system for thirty-1iter Niskin bottles. Nov 1988. 14p. NTIS NO. PB89-204 622/AS.

WHOI

88-55 Broadus, James M., Porter Hoag1and, III and Hauke L. Kite-Powe11.

Determining the structure of the United States marine instrumentation industry and its position in the world industry. Nov 1988. 199p. NTIS NO. PB89-200 869/AS.

WHOI

88-56 DeLonga, David $\mathrm{M}$.

A control system design technique for nonlinear discrete time systems. Ph.D. Thesis. MIT/WHOI Joint Program in

Oceanography and Oceanographic Engineering. Nov 1988. 239p. NTIS NO. AD-A203 687. 
WHOI

88-57 Rarles, Jennifer, Lawrence Pratt, Peter Cornillon and Jesn-Francois Cayula. A compilation of digitized satellite imagery of the Gulf Stream $(1982,1983$, and 1985). Nov 1988. 111p. NTIS NO. $\mathrm{AD}-\mathrm{A} 210243$.

WHOI

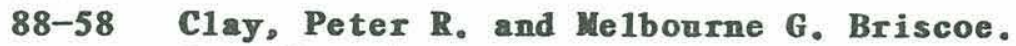

Rea1-Time Environmental Arctic Monitoring (R-Team) deployment cruise. Dec 1988. 53p. NTIS NO. AD-A203 856.

WHOI

88-59 Luyten, James $R_{\text {. and Henry M. Stome } 1 .}$ Exploring the North Atlantic 0cean on floppy disks. Dec 1988. 67p. plus (4) floppy disks. NTIS NO. AD-A205 733.

WHOI

88-60

DiPietro, David M.

Development of an active1y compliant underwater manipulator. S.M. Thesis. MIT/WHOI Joint Program in Oceanography and Oceanographic Engineering. Dec 1988. 100p.

WHOI

88-61 Hosom, David S., C1ifford L. Winget, Sumer We ismann, Dona1d P. Doucet and Janes F. Price.

Intelligent chilled mirror humidity sensor. Dec 1988. 85p. NTIS NO. AD-A205 135.

WHOI

88-62 Chapman, Robert J. and Richard $E_{\text {. Galat. }}$

Cooling the waters of the 17-meter flume at the Coasta1

Research Laboratory. Dec 1988. 20p. NTIS NO. PB89-203 996/AS.

WHOI

88-63 Pennington, Nancy J., Robert A. We11er and Kenneth H. Brink. Fronta1 Air-Sea Interaction Experiment (FASINEX) January-June 1986 FASINEX moored current meter array data report. WHOI meteorologica11y instrumented surface moorings (F2-845, F4-846, F6-847, F8-848, F10-849) WHOI 1ong term subsurface moorings. $(\mathrm{F} 1-829, \mathrm{~F} 12-830)$. Dec 1988. 292p. NTIS NO. AD-A209 604. 


\section{DEPARTMENT INDEX}

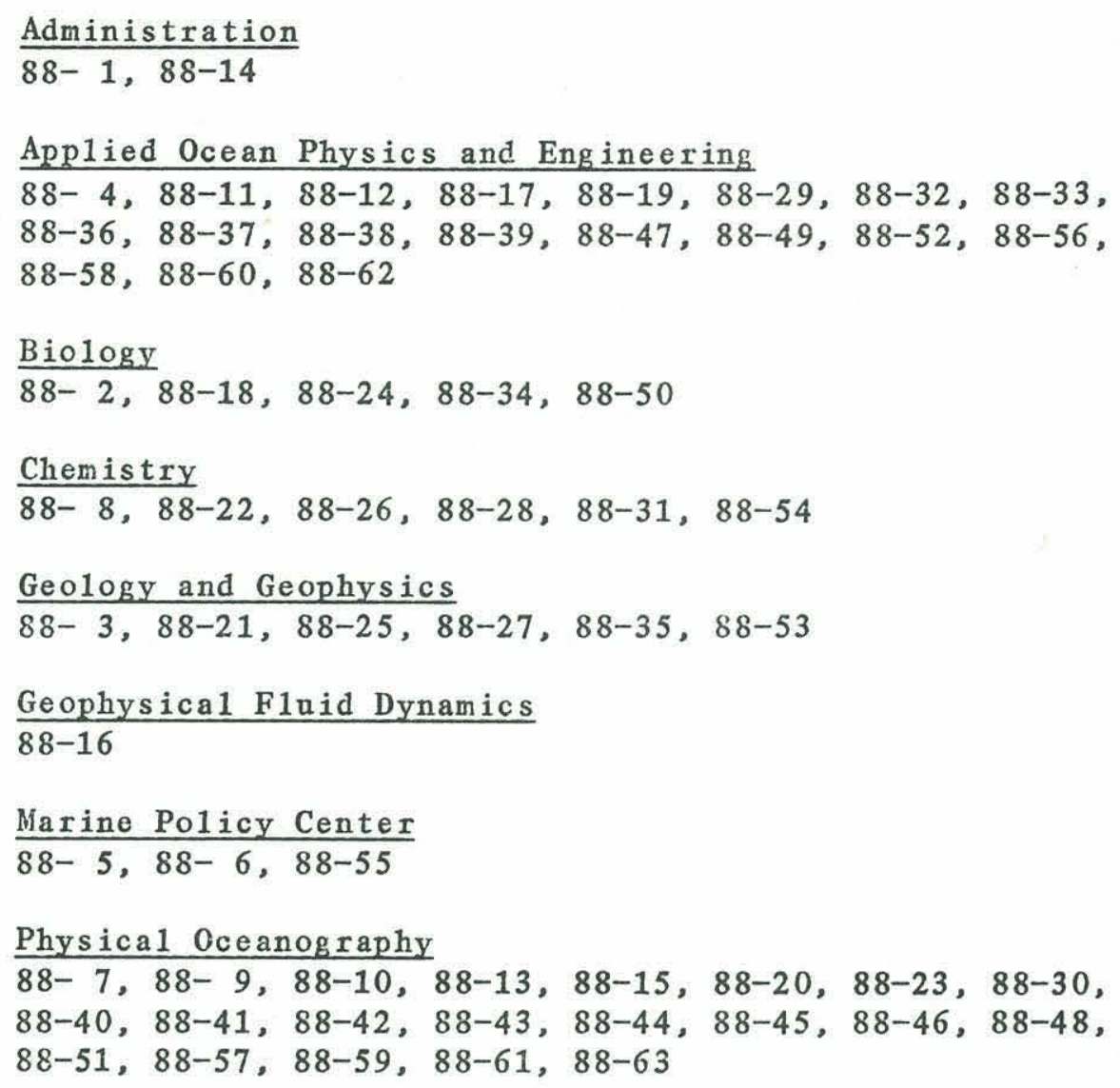




\section{AUTHOR INDEX}

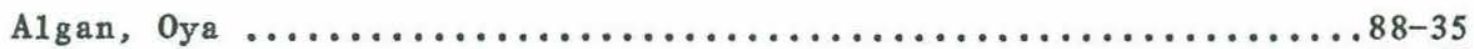

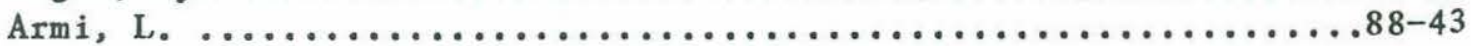

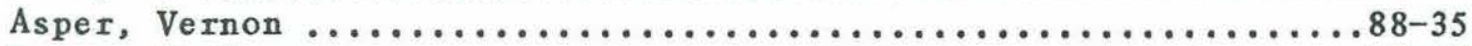

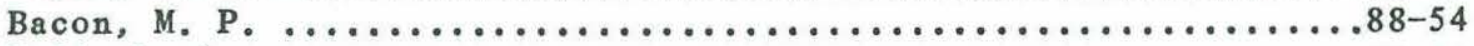

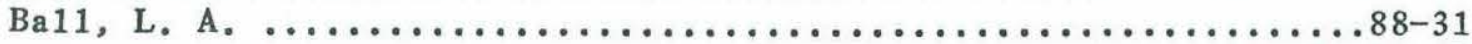

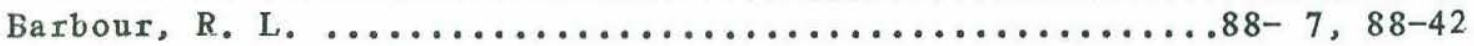

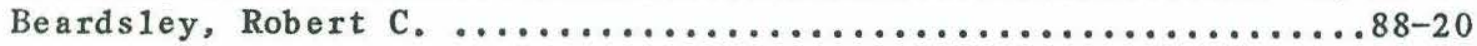

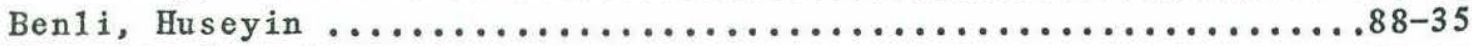

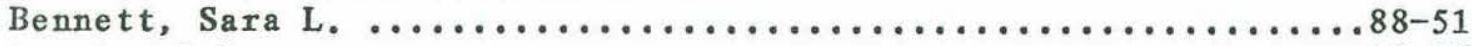

Benoit, Gaboury .................................

Berry, Mary Evans, Editor ............................

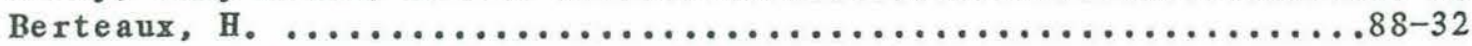

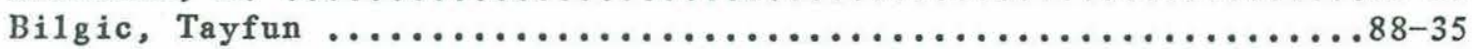

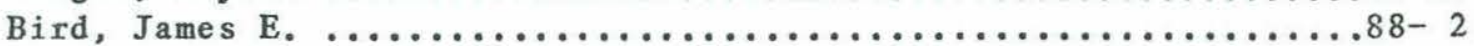

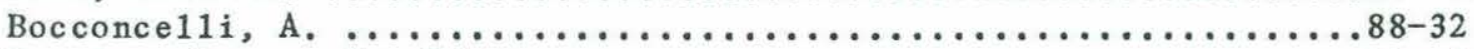

Brigham, Lawson W., Editor .......................... 5

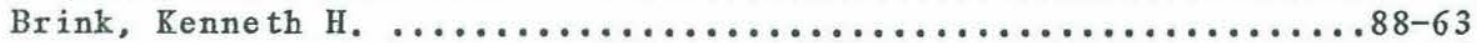

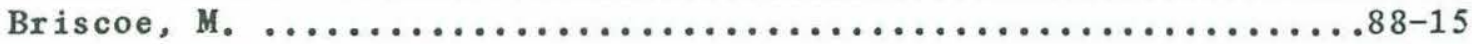

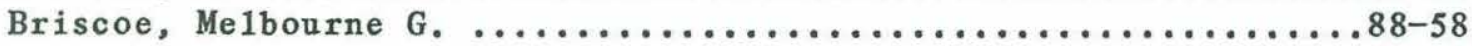

Broadus, James M. .................................

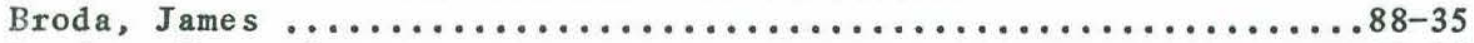

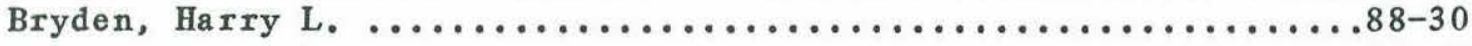

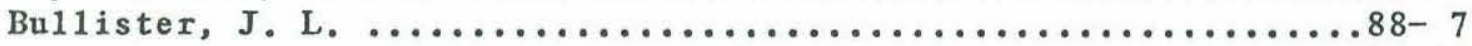

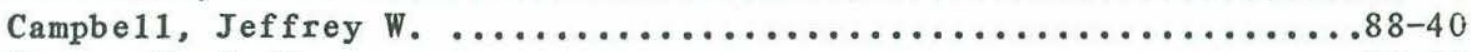

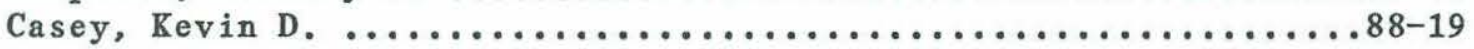

Casso, Susan A. .................................

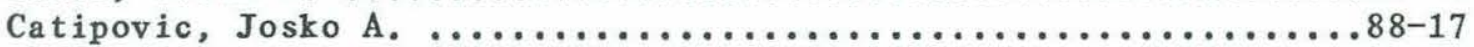

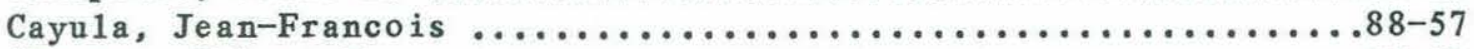

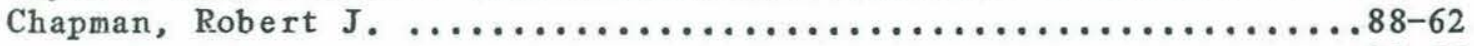

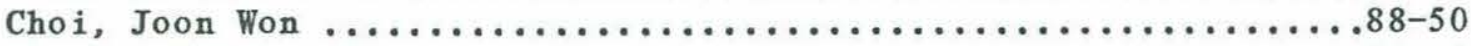

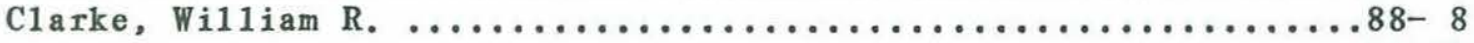

C1ay, Peter R. ......................................

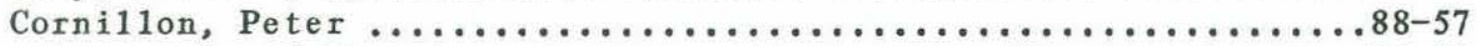

DeLonga, David M. ..................................

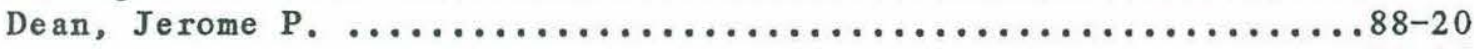

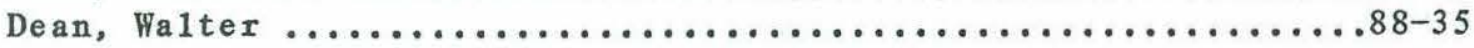

Degans, Egon T. .....................................

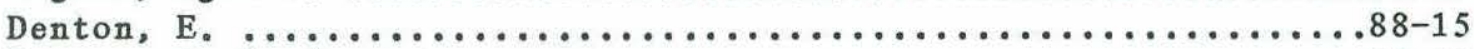

Derman, A. Sami ...................................

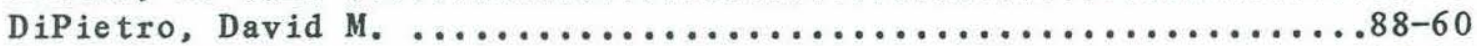

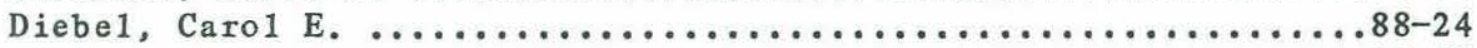

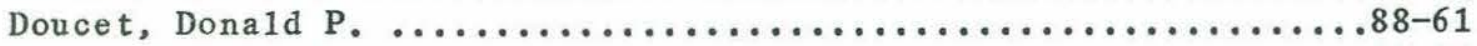

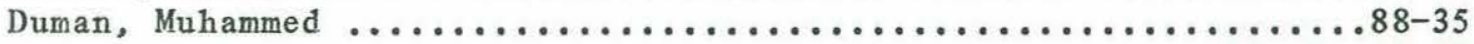

Dunworth, J. A. ............................. 7, 88-42

Earles, Jennifer ...................................

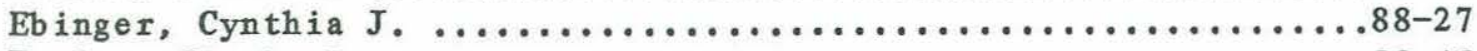

Freise, Clarke B. ..................................

Frye, D. .....................................

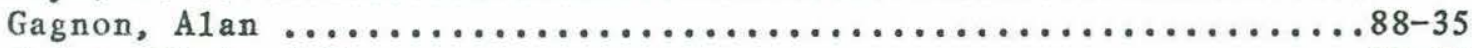

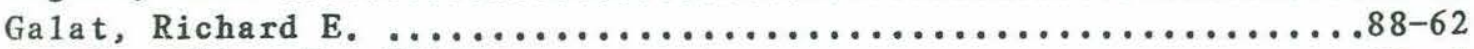

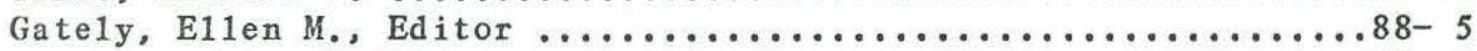

Goud, Margaret Redding ............................. 4 


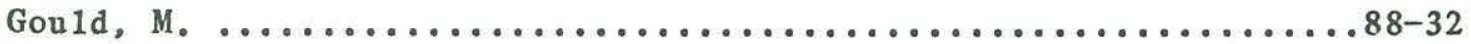

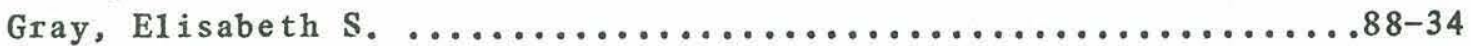

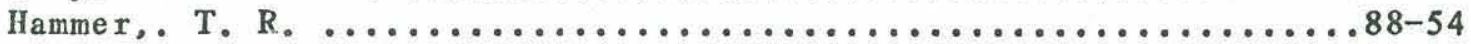

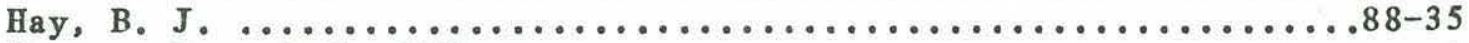

Hennet, Remy J-C., Editor ............................

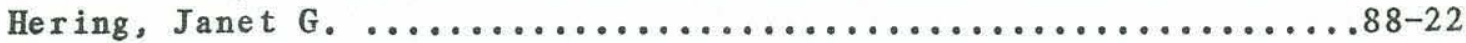

Hoagland, Porter, III ...............................

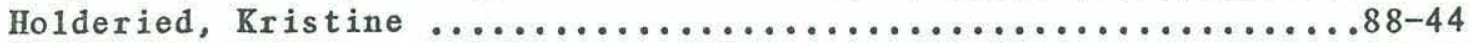

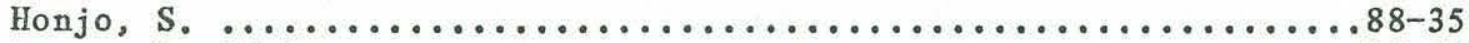

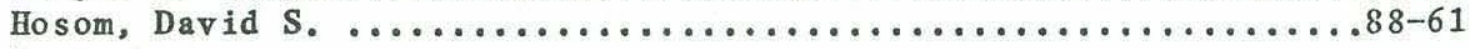

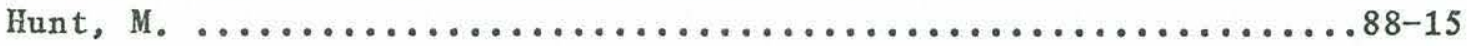

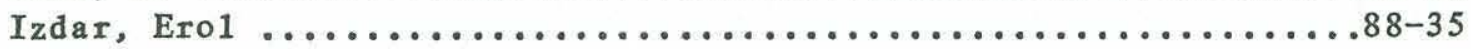

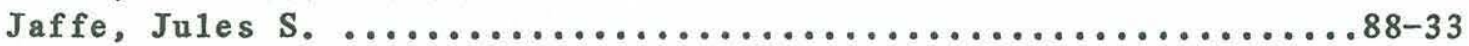

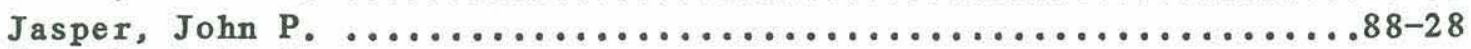

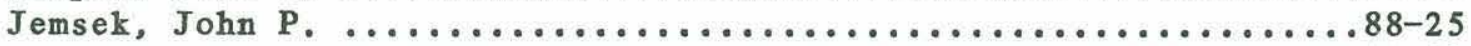

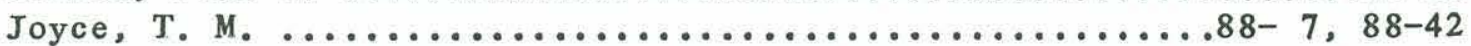

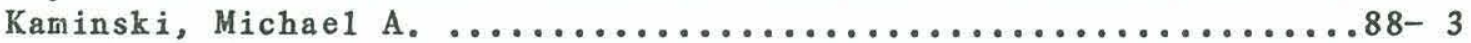

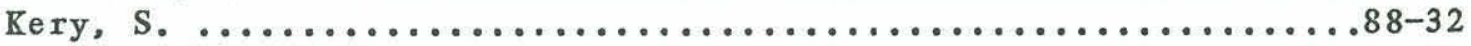

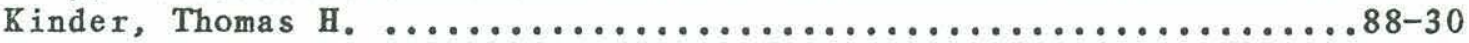

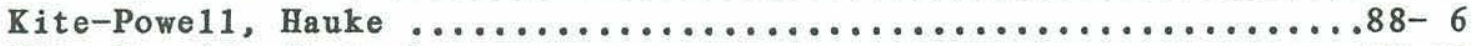

Kite-Powe 11, Hauke L. ....................................

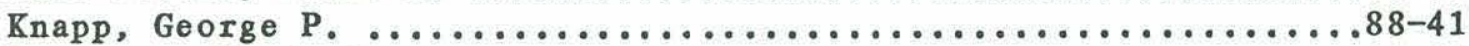

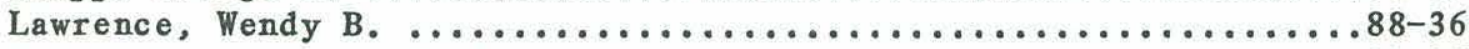

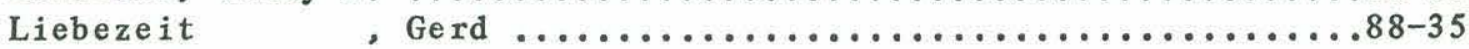

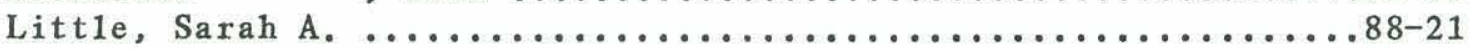

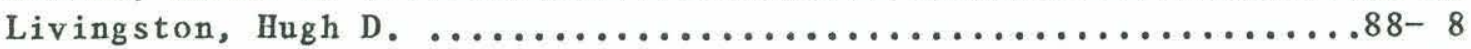

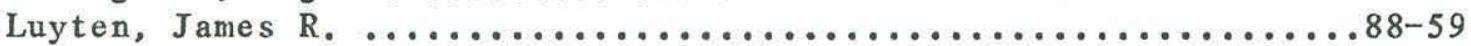

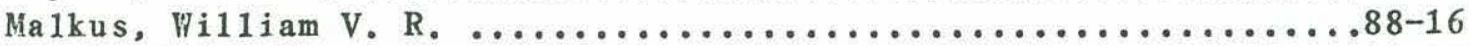

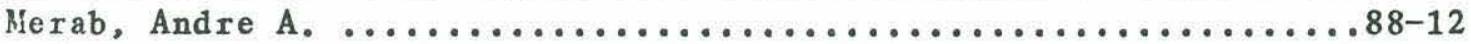

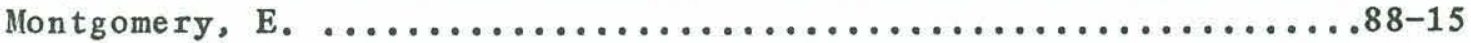

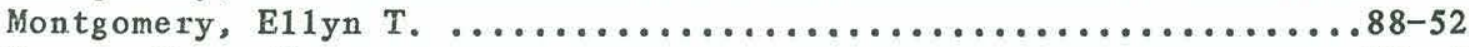

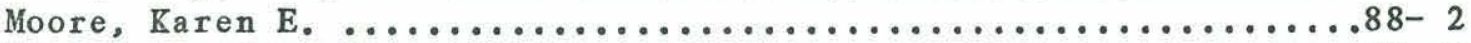

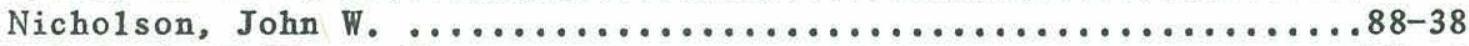

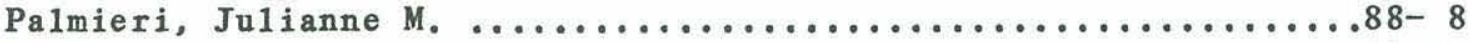

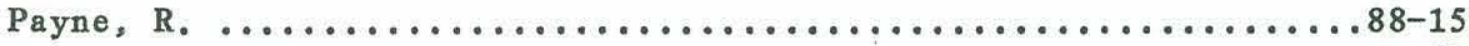

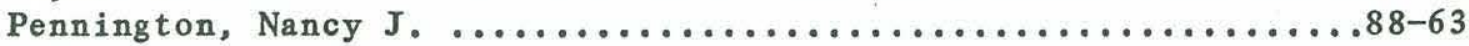

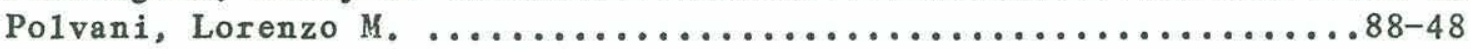

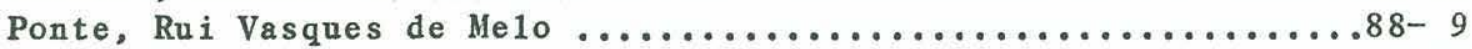

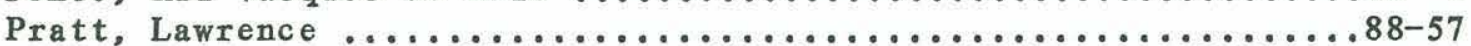

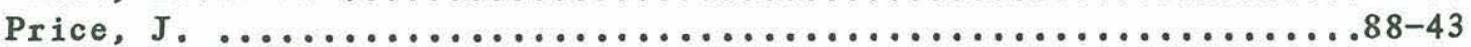

Price, James F. ..................................

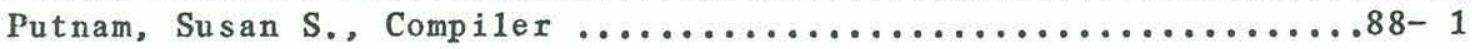

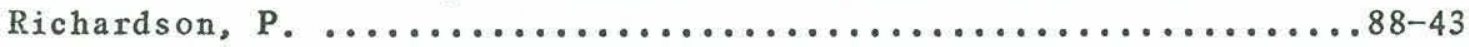

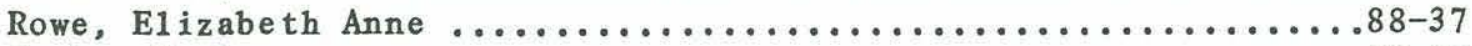

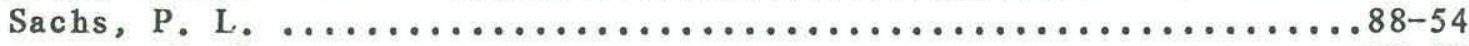

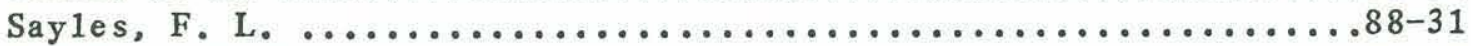

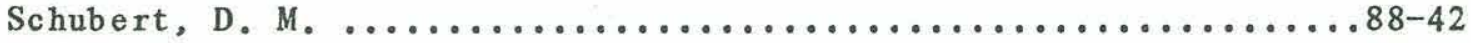

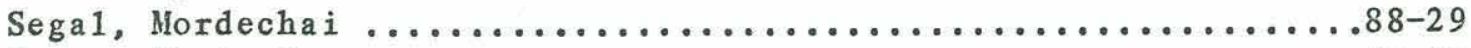

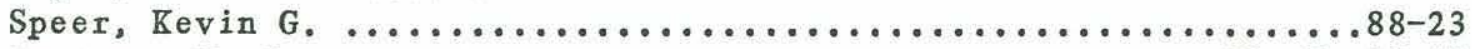

Sta1cup, M. C. .................................. $88-48$

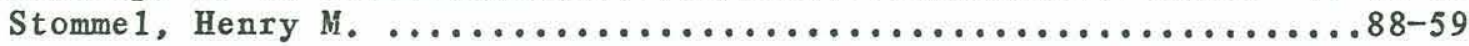

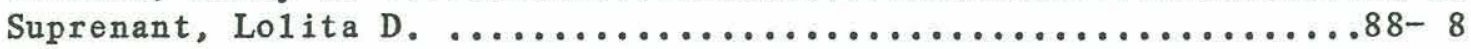

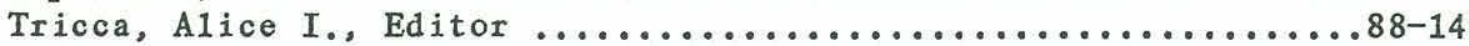

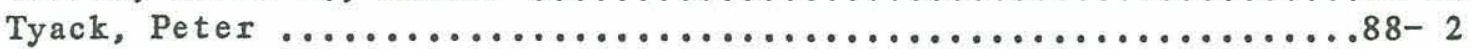

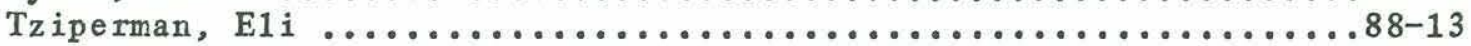




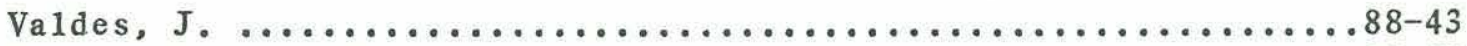

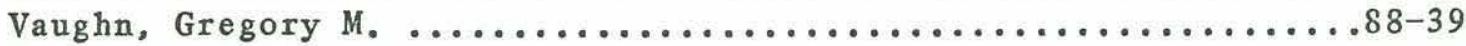

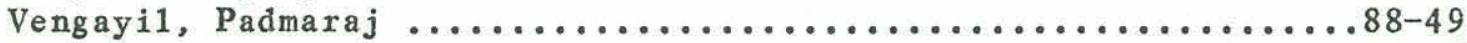

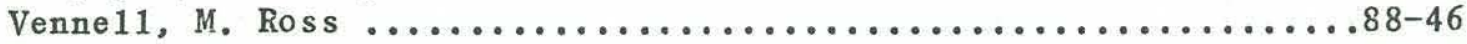

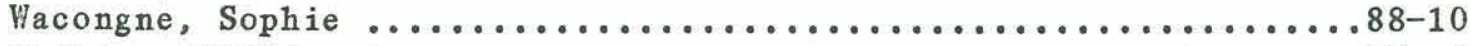

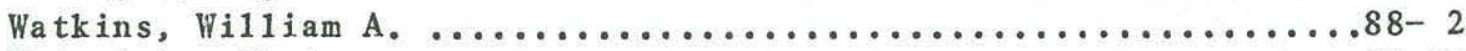

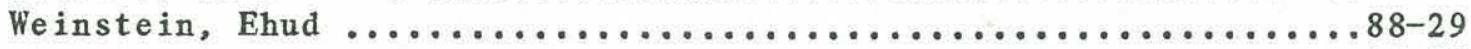

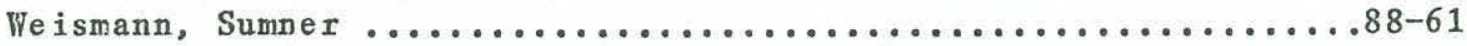

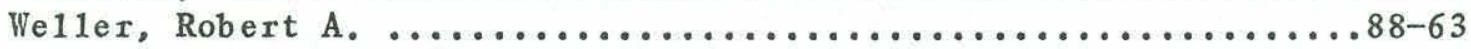

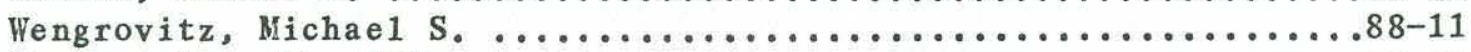

Whe 1 an, Jean $K_{.}$, Editor ................................ $88-53$

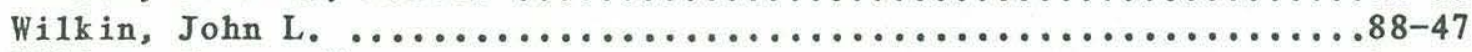

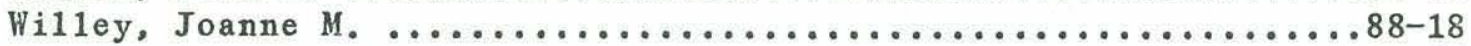

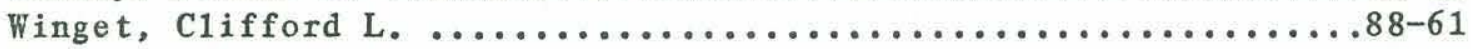

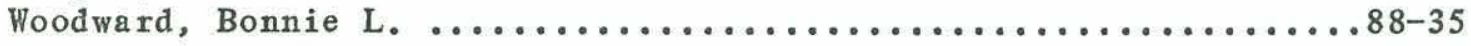

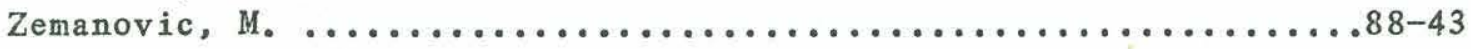




\section{FUNDING AGENCIES}

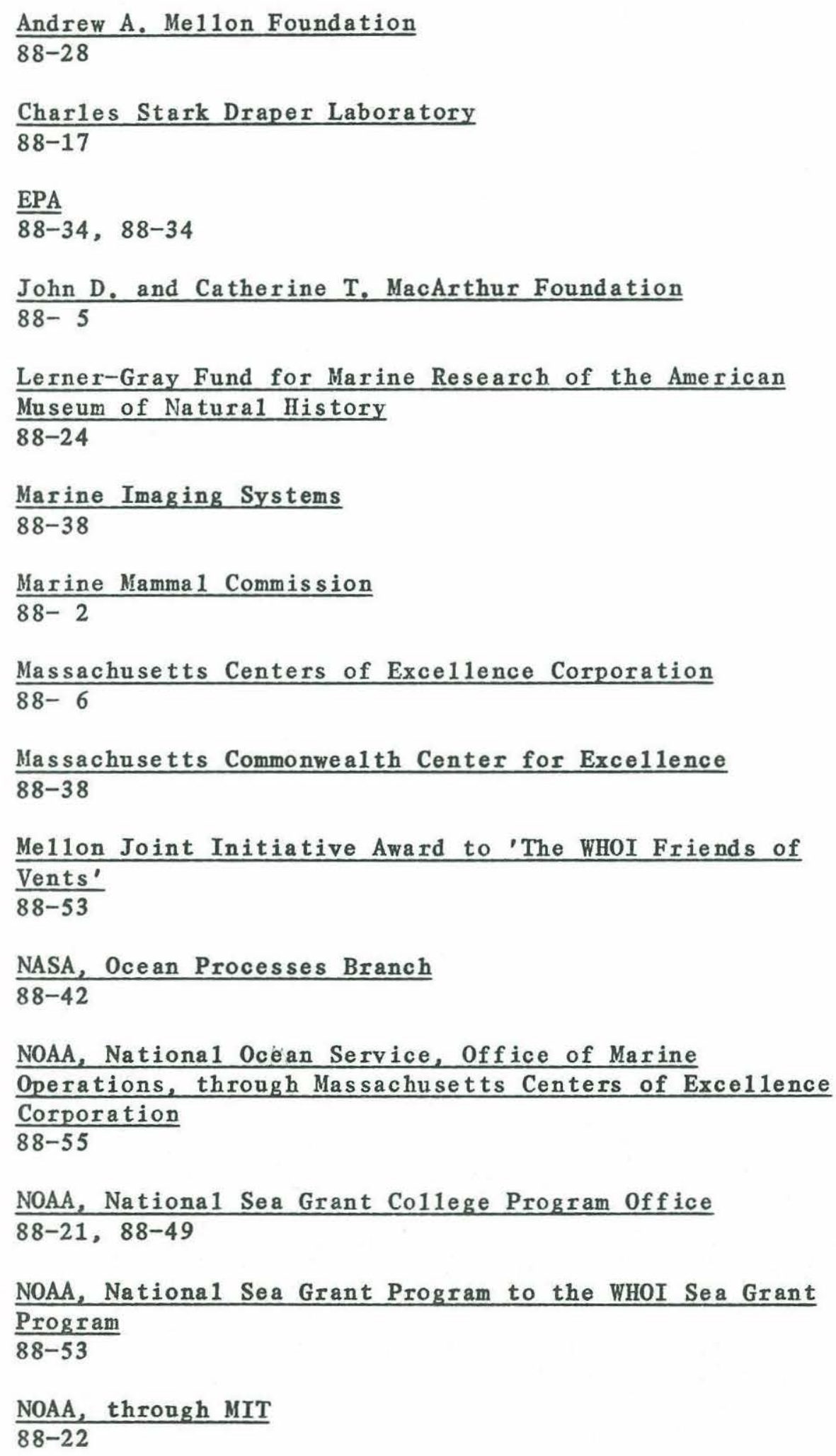




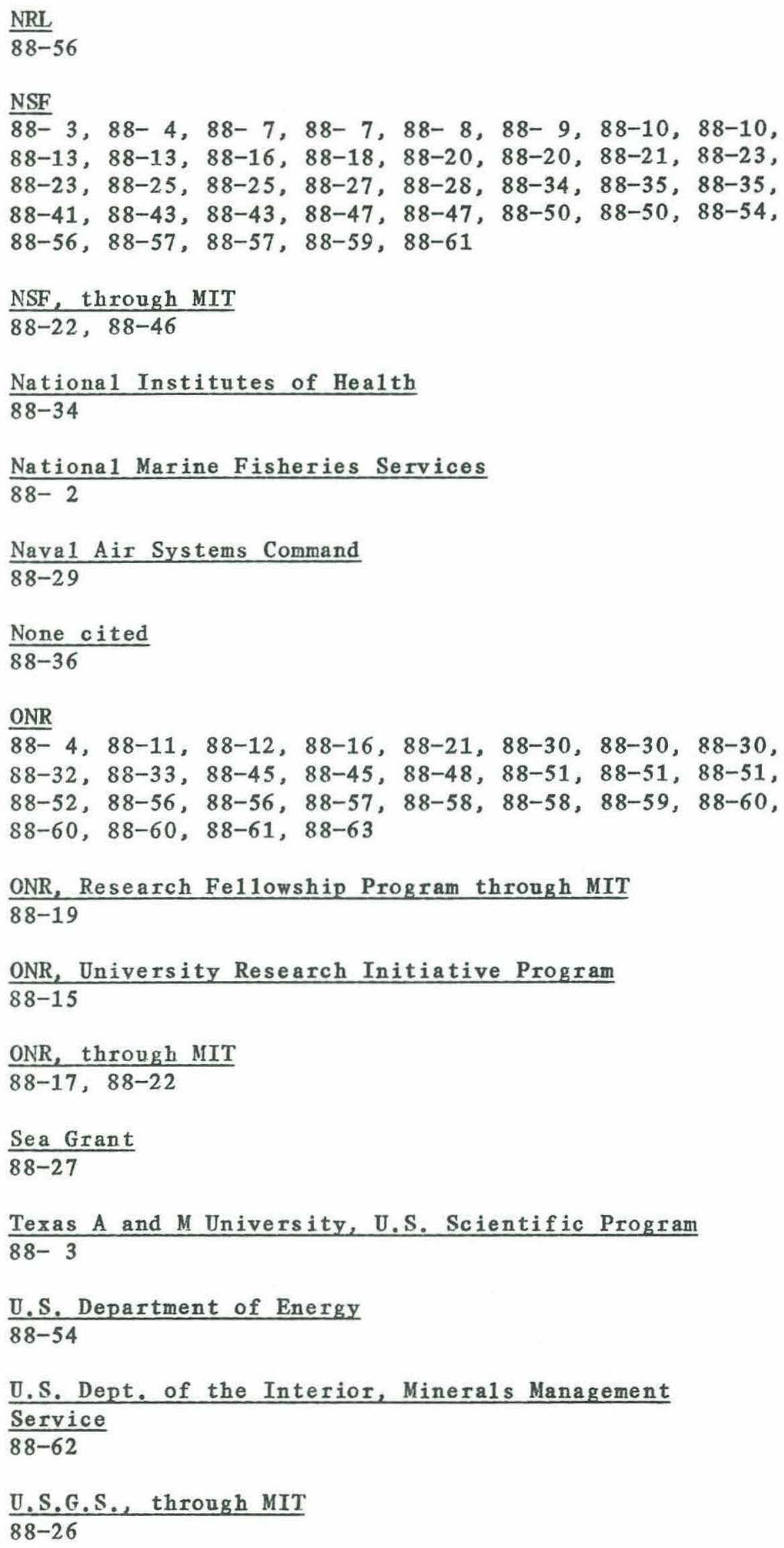


United States Navy

$88-38,88-39,88-40,88-44,88-45$

WHOI Coasta1 Research Center

$88-62$

WHOI Marine Policy Center

$88-6$

WHOI/MIT Joint Program Ocean Ventures Fund

$88-23$ 


\section{BIBLIOGRAPHIBS OF TBCHNICAL REPORTS}

\section{WHOI REF. TITLE}

$\begin{array}{ll}81-9 & \text { Bibliography of Reports, } 1980 \\ 82-14 & \text { Bibliography of Reports, } 1981 \\ 83-2 & \text { Bibliography of Reports, 1982 } \\ 84-1 & \text { Bibliography of Reports, 1983 } \\ 85-2 & \text { Bibliography of Reports, 1984 } \\ 86-4 & \text { Bibliography of Reports, 1985 } \\ 87-5 & \text { Bibliography of Reports, } 1986 \\ 88-1 & \text { Bibliography of Reports, } 1987\end{array}$

NIIS ORDER NUMBER

PB81-185167

PB81-237579

PB83-191064

PB84-173798

PB85-201747

PB86-214756/AS

PB87-200226/LL

PB88-201942/AS

\section{SUMMARIBS}

WHOI REF. TITLE

$\begin{array}{ll}81-36 & \text { Abstracts of papers submitted in } 1980 \text { for pub1ication } \\ 82-9 & \text { Abstracts of papers submitted in } 1981 \text { for publication } \\ 83-3 & \text { Abstracts of papers submitted in } 1982 \text { for publication } \\ 84-11 & \text { Abstracts of papers submitted in } 1983 \text { for publication } \\ 85-9 & \text { Abstracts of papers submitted in } 1984 \text { for publication } \\ 86-2 & \text { Abstracts of papers submitted in } 1985 \text { for publication } \\ 87-6 & \text { Abstracts of papers submitted in } 1986 \text { for pub1ication } \\ 88-14 & \text { Abstracts of papers submitted in } 1987 \text { for publication }\end{array}$

GEOPHYSICAL FLUID DYNAMICS

WHOI REF. TITLE

$81-102$
$82-45$
$83-41$
$84-44$
$85-36$
$86-45$
$88-16$
$89-26$

Physics of convection. Particle motions in fluids. Baroclinic instability and ocean fronts. Dynamic differentiations. Chaos.

Order and disorder in turbulent shear flow. Order and disorder in planetary dynamos. The influence of convection on large-scale circulations.
NIIS ORDER NUMBRR
AD-A114 $366 / 8$
AD-A122 864
$\mathrm{AD}-\mathrm{A} 166898$
AD-A149 386/5/XAB
AD-A164 601
AD-A177 571/7/XAB
AD-A196 554 


\section{DOCUMENT LIBRARY}

July 5, 1989

\section{Distribution List for Technical Report Exchange}

Attn: Stella Sanchez-Wade

Documents Section

Scripps Institution of Oceanography

Library, Mail Code C-075C

La Jolla, CA 92093

Hancock Library of Biology \& Oceanography

Alan Hancock Laboratory

University of Southern California

University Park

Los Angeles, CA 90089-0371

Gifts \& Exchanges

Library

Bedford Institute of Oceanography

P.O. Box 1006

Dartmouth, NS, B2Y 4A2, CANADA

Office of the International

Ice Patrol

c/o Coast Guard R \& D Center

Avery Point

Groton, CT 06340

Library

Physical Oceanographic Laboratory

Nova University

8000 N. Ocean Drive

Dania, FL 33304

NOAA/NESDIS Miami Library Center 4301 Rickenbacker Causeway

Miami, FL 33149

\section{Library}

Skidaway Institute of Oceanography

P.O. Box 13687

Savannah, GA 31416

Institute of Geophysics

University of Hawaii

Library Room 252

2525 Correa Road

Honolulu, HI 96822

Library

Chesapeake Bay Institute

4800 Atwell Road

Shady Side, MD 20876

MIT Libraries

Serial Journal Room 14E-210

Cambridge, MA 02139
Director, Ralph M. Parsons Laboratory

Room 48-311

MIT

Cambridge, MA 02139

Marine Resources Information Center

Building E38-320

MIT

Cambridge, MA 02139

Library

Lamont-Doherty Geological

Observatory

Colombia University

Palisades, NY 10964

Library

Serials Department

Oregon State University

Corvallis, OR 97331

Pell Marine Science Library

University of Rhode Island

Narragansett Bay Campus

Narragansett, RI 02882

Working Collection

Texas A\&M University

Dept. of Oceanography

College Station, TX 77843

Library

Virginia Institute of Marine Science

Gloucester Point, VA 23062

Fisheries-Oceanography Library

151 Oceanography Teaching Bldg.

University of Washington

Seattle, WA 98195

Library

R.S.M.A.S.

University of Miami

4600 Rickenbacker Causeway

Miami, FL 33149

Maury Oceanographic Library

Naval Oceanographic Office

Stennis Space Center

NSTL, MS 39522-5001

Marine Sciences Collection

Mayaguez Campus Library

University of Puerto Rico

Mayagues, Puerto Rico 00708 


\begin{tabular}{|c|c|c|c|}
\hline $\begin{array}{l}\text { REPORT DOCUMENTATION } \\
\text { PAGE }\end{array}$ & $\begin{array}{l}\text { 1. REPORT NO. } \\
\text { WHOI-89-43 }\end{array}$ & 2. & 3. Recipient's Accession No. \\
\hline \multirow{2}{*}{\multicolumn{2}{|c|}{$\begin{array}{l}\text { 4. Title and Subtitle } \\
\text { Bibliography of Technical Reports } \\
1988\end{array}$}} & & $\begin{array}{l}\text { 5. Report Date } \\
\text { Octrober, } 1989\end{array}$ \\
\hline & & & 6. \\
\hline \multicolumn{2}{|l|}{$\begin{array}{l}\text { 7. Author(s) } \\
\text { Compiled by Susan S. Putnam }\end{array}$} & & $\begin{array}{l}\text { 8. Performing Organization Rept. No. } \\
\text { WHOI-89-43 }\end{array}$ \\
\hline \multirow{2}{*}{\multicolumn{2}{|c|}{$\begin{array}{l}\text { 9. Performing Organization Name and Address } \\
\text { The Woods Hole Oceanographic Institution } \\
\text { Woods Hole, Massachusetts } 02543\end{array}$}} & & 10. Project/Task/Work Unit No. \\
\hline & & & $\begin{array}{l}\text { 11. Contract(C) or Grant(G) No. } \\
\text { (C) } \\
\text { (G) }\end{array}$ \\
\hline \multirow{2}{*}{\multicolumn{2}{|c|}{$\begin{array}{l}\text { 12. Sponsoring Organization Name and Address } \\
\text { Woods Hole Oceanographic Institution }\end{array}$}} & & $\begin{array}{l}\text { 13. Type of Report \& Period Covered } \\
\text { Technical Report }\end{array}$ \\
\hline & & & 14. \\
\hline
\end{tabular}

15. Supplementary Notes

This report should be cited as: Woods Hole Oceanog. Inst. Tech. Rept., WHOI-89-43,

16. Abstract (Limit: 200 words)

The technical reports prepared by the Woods Hole Oceanographic Institution in 1988 are listed in this bibliography. Inquiries about availability of extra copies will be handled on an individual basis. Initial distribution of the reports is controlled by the funding agencies. Reports are available through the:

\section{National Technical Information Service \\ NTIS Order Desk \\ 5285 Port Royal Road \\ Springfield, VA 22161}

NTIS order numbers are included with each report listed or can be obtained through the Document Library.

The Document Library provides Interlibrary Loan service for all Institution reports and will assist with problems of identification.

17. Document Analysis a. Descriptors

b. Identifiers/Open-Ended Terms

c. COSATI Fleld/Group

18. Availability Statement

Approved for publication; distribution unlimited.

\begin{tabular}{|l|l|}
\hline $\begin{array}{c}\text { 19. Security Class (This Report) } \\
\text { UNCLASSIFIED }\end{array}$ & $\begin{array}{c}\text { 21. No. of Pages } \\
18\end{array}$ \\
\hline 20. Security Class (This Page) & 22. Price \\
\hline
\end{tabular}

